\title{
Thyroid malignant neoplasm-associated biomarkers as targets for oncolytic virotherapy
}

This article was published in the following Dove Press journal:

Oncolytic Virotherapy

21 June 2016

Number of times this article has been viewed

\author{
Mingxu Guan' \\ Yanping $\mathrm{Ma}^{2}$ \\ Sahil Rajesh Shah ${ }^{3}$ \\ Gaetano Romano3 \\ 'Virology, Research and Development, \\ Zoetis Inc., Kalamazoo, MI, USA; \\ ${ }^{2}$ Virology Laboratory, Shengjing \\ Hospital, China Medical University, \\ Shenyang, Liaoning, People's Republic \\ China; ${ }^{3}$ Department of Biology, \\ College of Science and Technology, \\ Temple University, Philadelphia, PA, \\ USA
}

\begin{abstract}
Biomarkers associated with thyroid malignant neoplasm (TMN) have been widely applied in clinical diagnosis and in research oncological programs. The identification of novel TMN biomarkers has greatly improved the efficacy of clinical diagnosis. A more accurate diagnosis may lead to better clinical outcomes and effective treatments. However, the major deficiency of conventional chemotherapy and radiotherapy is lack of specificity. Due to the macrokinetic interactions, adverse side effects will occur, including chemotherapy and radiotherapy resistance. Therefore, a new treatment is urgently needed. As an alternative approach, oncolytic virotherapy may represent an opportunity for treatment strategies that can more specifically target tumor cells. In most cases, viral entry requires the expression of specific receptors on the surface of the host cell. Currently, molecular virologists and gene therapists are working on engineering oncolytic viruses with altered tropism for the specific targeting of malignant cells. This review focuses on the strategy of biomarkers for the production of novel TMN oncolytic therapeutics, which may improve the specificity of targeting of tumor cells and limit adverse effects in patients.
\end{abstract}

Keywords: thyroid malignancy neoplasm, biomarkers, oncolytic virotherapy

\section{Introduction}

Thyroid malignant neoplasm (TMN) is a common endocrine malignancy. Currently, fine-needle aspiration (FNA) cytology and ultrasonography are utilized for clinical diagnosis of thyroid nodules. Data from clinical epidemiological studies indicate that $\sim 40 \%$ of adult population has at least a single thyroid nodule. Frequently, these nodules are benign.

In most cases, up to $65 \%$ of patients with clinically normal thyroid glands have one or more grossly visible nodules, whereas the incidence of malignancy is $2 \%-4 \%{ }^{1}$ Statistical epidemiology shows that papillary thyroid carcinoma (PTC) comprises $80 \%-85 \%$ of all thyroid neoplasms, which is frequent in young females with excellent prognosis. Follicular thyroid carcinoma (FTC) accounts for $\sim 10 \%-15 \%$ of cases. PTC and FTC belong to the low-risk group, have a low recurrence rate $(<5 \%)$, and have an excellent survival rate $(>98 \%))^{2}$ The least common histotype is anaplastic thyroid carcinoma (ATC; $1 \%-2 \%$ ), which has a rapid progression and a very poor prognosis with a mean survival time of 2-6 months. Finally, medullary thyroid carcinoma originates from thyroid parafollicular calcitonin-producing cells and accounts for $\sim 4 \%$ of all thyroid malignancies.

Since PTC is the most common thyroid malignancy, there is no issue with diagnosis. Conversely, the follicular variant of PTC often poses a diagnostic challenge. The
Correspondence: Mingxu Guan Virology, Research and Development, Zoetis Inc., 333 Portage Street, Kalamazoo, MI 49007, USA Email mingxuguan@gmail.com
Oncolytic Virotherapy 2016:5 35-43

(c) (1) (8) ๑ 2016 Guan et al. This work is published and licensed by Dove Medical Press Limited. The full terms of this license are available at https:///www.dovepress.com/terms. cc. you herbby accept the Terms. Non-commercial uses of the work are permitted without any further permission from Dove Medical Press Limited, provided the work is properly attributed. For permission for commercial use of this work, please see paragraphs 4.2 and 5 of our Terms (https://www.dovepress.com/terms.php).
Dovepress

http://dx.doi.org/10.2147/OV.S99856
35 
distinction between these two lesions is important, because prognosis and management are different. ${ }^{3}$ The detection and management of TMN remains dependent on histological examination, which is the standard for diagnosis. Although FNA biopsy is the most useful diagnostic tool in evaluating a thyroid nodule, preoperative diagnosis of thyroid nodules is frequently imprecise and needs immunohistochemical (IHC) stains to aid in the confirmation of TMN. Therefore, FNA cytology is combined with immunocytochemical biomarker staining, which will improve the diagnostic accuracy in clinical practice. The prognostic use of tumor markers is currently well established and allows for a rapid and accurate diagnosis, ${ }^{4}$ which, in turn, may result in a prompt and more efficacious clinical TMN management. The most effective treatment of thyroid cancer consists of surgical thyroid gland removal, followed by radioactive ablation and thyroid-stimulating hormone (TSH) suppression therapy and/or chemotherapy, depending on the type and stage of the disease. Chemotherapy and radiation work by destroying these fast-growing cells. Unfortunately, other types of fast-growing healthy cells can also be damaged along with cancer cells, causing side effects such as pain, flu-like symptoms, nausea, vomiting, fatigue, hair loss, anemia, and lymphedema. In the worst-case scenario, some tumors are resistant to chemotherapy and radiation therapy. Consequently, the complications of side effects are unacceptable. ${ }^{5}$ It has been noted that a major deficiency with conventional chemotherapy and radiotherapy is their specificity. For this reason, a new treatment strategy is urgently needed. In this respect, oncolytic therapy might represent a valid alternative to chemo- and/or radiotherapies. Oncolytic viruses are genetically engineered to replicate only in malignant cells. As a result, the infected tumor cells are lysed and several progeny virions are released, infecting neighboring cells. In the meantime, the infection induces antitumor immune responses. Oncolytic viruses can also be administered intravenously, in order to search and destroy circulating malignant cells and cancer stem cells (CSCs).

In general, the efficacy of binding to the surface of a given target cell by a virus depends on the presence of specific viral receptors. In some cases, more than one cell surface molecule is required to permit viral entry. Interestingly, the oncolytic virus tropism can be redirected or modified in order to enhance the specificity for targeting of cancer cells. In the past decade, thyroid tumor markers have been identified and characterized. This provided the tools for earlier and more accurate diagnosis, prediction of treatment efficacy, and post-intervention follow-up of patients. ${ }^{6,7}$ In fact, tumor-specific biomarkers have been investigated since the early 1970 s. ${ }^{8}$ Currently, thyroid biomarkers combined with FNA have emerged as important instruments for TMN diagnosis in the clinical setting. ${ }^{9}$ These findings had a significant impact on biotechnology development and anticancer oncolytic virotherapy.

\section{The biomarkers for TMN oncolytic virotherapy}

Biomarkers are widely used for clinical diagnosis and monitoring. Up-to-date, $\sim 80$ biomarkers have been studied for TMN diagnosis and research programs, which include receptors, enzymes, and related antigens. For TMN oncolytic virus design, we discuss seven important thyroid cell membrane biomarkers that would be useful for oncolytic virotherapy. As for the selection criteria, we have carefully compared the sensitivity and specificity in the detection of clinical TMN specimens and tissue distribution as shown in Tables $1^{10}$ and $2 .{ }^{11}$

\section{Thyrotropin receptor}

The thyrotropin receptor (TSHR) is encoded by the TSHR gene. The TSHR gene maps to human chromosome 14q31 and encodes a seven-transmembrane G-protein-coupled glycoprotein. Total molecular masses are $90-500 \mathrm{kDa}$, with subunits

Table I Estimated protein expression of TMN biomarkers

\begin{tabular}{|c|c|c|c|c|c|c|c|c|c|c|}
\hline \multicolumn{11}{|c|}{ Estimated protein expression $\log _{10}(\mathrm{ppm})$} \\
\hline Biomarker & Serum & Plasma & Platelet & Liver & Heart & Lung & Brain & Kidney & Pancreas & Adipocyte \\
\hline TSHR & - & 1 & $>0$ & - & - & - & 0 & - & - & - \\
\hline TPO & - & $>1$ & $>-1$ & $<1$ & I & - & - & - & - & - \\
\hline NIS & - & I & - & - & - & - & - & - & - & - \\
\hline CDI33 & - & $<1$ & 0 & - & - & 2 & - & - & - & - \\
\hline CD44 & 2 & $>1$ & $>1$ & $<3$ & $<2$ & 2 & $>1$ & $>0$ & 3 & - \\
\hline CAV-I & - & - & 0 & I & 3 & $>2$ & - & 2 & - & 4 \\
\hline LGAL3 & - & $<1$ & $>1$ & - & $<3$ & $>1$ & 2 & $>1$ & - & - \\
\hline
\end{tabular}

Note: - indicates that the value is below zero as reported by Safran et al. ${ }^{10}$

Abbreviations: CAV-I, Caveolin-I; NIS, sodium/iodide symporter; CD, cluster of differentiation; LGAL3, galectin-3; ppm, parts per million; TMN, thyroid malignant neoplasm; TPO, thyroid peroxidase; TSHR, thyrotropin receptor. 
Table 2 TMN biomarkers in subcellular locations

\begin{tabular}{|c|c|c|c|c|c|c|c|c|c|}
\hline \multirow[t]{2}{*}{ Biomarker } & \multicolumn{9}{|c|}{ Subcellular locations from compartment and confidence number from 0 to $5^{a}$} \\
\hline & Extracellular & Plasma & Cytosol & $\begin{array}{l}\text { Nucleus } \\
\text { endoplasmic }\end{array}$ & Endosome & $\begin{array}{l}\text { Golgi } \\
\text { lysosome }\end{array}$ & Mitochondrion & $\begin{array}{l}\text { Space } \\
\text { membrane }\end{array}$ & $\begin{array}{l}\text { Reticulum } \\
\text { apparatus }\end{array}$ \\
\hline TSHR & I & 2 & 5 & I & 1 & 0 & 0 & 0 & 0 \\
\hline TPO & 2 & 4 & 2 & 2 & 2 & 2 & 2 & 1 & 2 \\
\hline NIS & 4 & 4 & 0 & 5 & 0 & 0 & 0 & 0 & 0 \\
\hline CDI33 & 2 & 5 & I & 2 & I & 0 & 0 & 0 & 0 \\
\hline CD44 & 3 & 5 & 0 & 2 & I & I & 4 & 0 & 1 \\
\hline CAV-I & 2 & 5 & 2 & 2 & 5 & 5 & 5 & 1 & I \\
\hline LGAL3 & 5 & 4 & 3 & 5 & 0 & I & 0 & I & 5 \\
\hline
\end{tabular}

Notes: aConfidence number 0-5: It graphically summarizes the types of evidence supporting the localization by Binder et al."

Abbreviations: CAV-I, caveolin-I; NIS, sodium/iodide symporter; CD, cluster of differentiation; LGAL3, galectin-3; TMN, thyroid malignant neoplasm; TPO, thyroid peroxidase; TSHR, thyrotropin receptor.

varying in mass from $15 \mathrm{kDa}$ to $90 \mathrm{kDa} \cdot{ }^{12,13} \mathrm{TSHR}$ is a major controller of thyroid cells that responds to TSH and stimulates the production of thyroxine $\left(\mathrm{T}_{4}\right)$ and triiodothyronine $\left(\mathrm{T}_{3}\right)$. The TSHR receptor is primarily found on the surface of the thyroid epithelial cells. The binding of soluble thyrotropin to its receptor activates adenylyl cyclase and intercellular levels of cAMP rise. cAMP activates all functional aspects of the thyroid cell, including iodine pumping; thyroglobulin synthesis, iodination, endocytosis, and proteolysis; thyroid peroxidase (TPO) activity; and hormone release. ${ }^{14} \mathrm{~A}$ positive thyroid tissue staining was observed exclusively along the basal cell surface of the flattened follicular cell tissues using a monoclonal antibody against the $\mathrm{C}$-terminal region of human TSHR. ${ }^{15,16}$

TSHR expression is higher than other biomarkers in thyroid follicular cells in physiological and pathological circumstances. Normally, the expression levels of TSHR and of TPO in the thyroid are approximately fourfold, which is higher than sodium/iodide symporter (NIS). ${ }^{17}$ TSHR expression levels have been associated with TMN progression. Low expression of TSHR predicts a poor prognosis in TMN. Tanaka et $\mathrm{a}^{18}$ showed that low expression of TSHR in the recurrent tissue was strongly related to a poorer outcome in patients with PTC. In recent years, molecular diagnostic tests such as reverse transcription polymerase chain reaction (RT-PCR) have been increasingly used in clinical laboratories and research programs. The circulating TSHR-mRNA levels were measured in 19 patients with differentiated thyroid cancer (DTC) using RT-PCR. The sensitivity was $100 \%$ and the specificity was $98 \% .{ }^{19} \mathrm{~A}$ similar study indicated that the positive predictive value and specificity were $81 \%$ and $83 \%$, respectively, in 374 patients. Moreover, the TSHR-mRNA positive predictive value, specificity, and accuracy in 54 patients with FTC were $96 \%, 96 \%$, and $85 \%$, respectively. ${ }^{20}$ The results of high sensitivity and specificity may prove that the TSHR has high levels of expression in patients with PTC. Conversely, $\sim 10 \%$ of TMN lost TSH responsiveness. ${ }^{21}$

\section{NIS}

The NIS is a solute carrier family 5 (SLC5A5) protein encoded by the SLC5A5 gene, which is located on chromosome 19p13.11 in humans. The gene size of NIS is 23,202 bp, encoding a transmembrane glycoprotein. The proteins are 643 amino acids in length with a molecular weight of $87 \mathrm{kDa}$ and 13 transmembrane domains. The protein contains three potential N-linked glycosylation sites, which transport two sodium cations $\left(\mathrm{Na}^{+}\right)$for each iodide anion $\left(\mathrm{I}^{-}\right)$into the follicular cells of the thyroid gland for synthesis of thyroid hormone. ${ }^{22}$ In addition to TSH, other factors can also influence NIS expression, such as thyroid iodine content, insulin, insulin-like growth factor, transforming growth factor $\beta 1$, tumor necrosis factor $\alpha$, interferon $\gamma$, interleukin (IL)- $1 \alpha$, IL-1 $\beta$, and IL-6. ${ }^{23-25}$ NIS is highly expressed in the thyroid. Low levels of NIS in other extra thyroidal tissues have been detected by IHC and/or RT-PCR, but it is not clear to what extent it is active in these tissues. ${ }^{26}$

Clinical studies have shown that the NIS mRNA was detected in $32 \%(11 / 34)$ of DTC patients..$^{27}$ The NIS protein was detected in $35 \%(8 / 23)$ of patients with PTC, $44 \%(4 / 9)$ of patients with FTC, $25 \%(2 / 8)$ of patients with benign tumors, and $100 \%(4 / 4)$ of patients with autoimmune lesions. ${ }^{28}$ However, compared with normal thyroid tissue, the levels of NIS expression in thyroid carcinomas were markedly reduced $^{29,30}$ and $\sim 10 \%-20 \%$ DTCs do not express the NIS gene. ${ }^{31}$ NIS has been incorporated into a remarkable variety of viral and nonviral vectors such as oncolytic herpes simplex virus, adenovirus, and measles virus that were engineered to express the NIS. The oncolytic viruses are selectively destructive to a variety of human tumor cell types. The virus spread in vivo can be monitored by noninvasive imaging of NIS gene 
expression. By administration of high dose radioiodine, the oncolytic virus potency can be boosted.

\section{TPO}

Thyroid peroxidase or thyroperoxidase (TPO) is a membranebound glycoprotein that belongs to the peroxidase family, XPO subfamily. TPO plays a key role in the thyroid hormone biosynthesis by catalyzing both the iodination of tyrosyl residues and the coupling of iodotyrosyl residues in thyroglobulin to form precursors of the thyroid hormones of $\mathrm{T}_{4}$ or $\mathrm{T}_{3}{ }^{32}$ In humans, TPO is encoded by the TPO gene. The TPO gene contains 17 exons and covers at least $150 \mathrm{~kb}$ of chromosome $2(2 \mathrm{p} 25) \cdot{ }^{33} \mathrm{TPO}$ is restricted to the apical plasma membrane of the follicular epithelial cells and comprises two identical subunits of $\sim 100 \mathrm{kDa}$ molecular weight each. The TPO gene includes the species coding for a 933-amino acid protein (termed TPO-1) and a second in which exon 10 is deleted thus is 57 residues shorter (termed TPO-2). ${ }^{34}$ The protein has several different isoforms, which vary by size and location within the cell. Some isoforms are inactive because they are not located in the cell membrane. TPO is stimulated by TSH, which upregulates gene expression. ${ }^{35}$ Because TPO catalyzes the iodination of proteins, iodide retention within thyroid cells may lead to rapid tumor cell death. ${ }^{34}$

Several groups had reported the expression of TPO protein and mRNA in TMN clinical samples. The sensitivities of various methods for the detection of TMN were distinct. The TPO had a sensitivity of $50 \%(12 / 24)$ in PTC specimens and $11 \%(1 / 11)$ in FTC specimens by IHC. ${ }^{36}$ The TPO mRNA expression was 70\% (7/10) in patients with known metastases, and 36\% (39/110) in patients without metastases. In the control group, the TPO mRNA was $7.4 \%$ (4/54). ${ }^{37}$ Ishikawa et al reported that the positive rate of TPO mRNA was $61 \%(14 / 23)$ in cases of stage I carcinoma, 4\% (2/49) in cases with benign thyroid disease, and negative in 20 healthy volunteers by RT-PCR. ${ }^{38}$ In contrast, two groups reported independently with different results as mentioned earlier that the expression of TPO is lost or decreased in patients with TMN. ${ }^{39,40}$

\section{CDI33}

Cluster of differentiation (CD)133 antigen (PROM1, promini-1, or AC133) is a $115-120 \mathrm{kDa}$ pentaspan membrane glycoprotein with five transmembrane domains, which localize to cellular protrusions. The CD133 in humans is encoded by the PROM1 gene on chromosome 4 (4p15). ${ }^{41}$ CD133 was initially described as a surface marker specific for human hematopoietic stem cells, endothelia progenitor cells, neuronal, glial stem cells, and adult stem cells. It has a low level of expression in the kidney, pancreas, placenta, and fetal liver tissue. The function of CD133 has been related to cell differentiation, proliferation, and apoptosis. ${ }^{42}$ CD133 has been frequently used as a biomarker for CSCs including leukemia cells and brain tumor cells, although its biological function is unclear. ${ }^{43}$

In previous studies of ATC cell lines, CD133-expressing cells have been shown to possess the characteristics of stem cells and have the ability to initiate tumors. CD133+ cells exhibited stem-cell-like features such as high proliferation, self-renewal, and colony-forming ability in vitro. $\mathrm{CD} 133^{+}$ ATC cells are responsible for tumor growth in immunodeficient mice, and it can be regulated by $\mathrm{TSH} .{ }^{44} \mathrm{Ke}$ et al analyzed the expression of selected pluripotent, differentiated thyroidspecific genes and genes related to epithelial-mesenchymal transition in both CD133 ${ }^{\text {pos }}$ and CD133 ${ }^{\text {neg }}$ cells derived from resected primary tumors. Cells expressing CD133 were isolated with magnetic microbeads, and total RNA was detected by real-time quantitative PCR. Thyroid specific gene expression was significantly higher in CD133 $3^{\text {neg }}$ than in CD133 $3^{\text {pos }}$ cells, including NIS (negative/positive $=2 \sim 4$ fold), $\mathrm{Tg}$ (negative/positive $=1.02 \sim 36$ fold), TPO (negative/positive $=1.1 \sim 3$ fold ) and TSHR (negative/positive $=1 \sim 2$ fold).$^{45}$ Liu and Brown detected the specimens of ATC, PTC, and FTC by IHC to examine the expression of stem cell markers (nestin, CD133, and CD44) and a marker for epithelial-mesenchymal transition (E-cadherin). Intense expressions of nestin, CD133, and CD44 and no expression of E-cadherin were observed in ATC. The expressions of CD133 and CD44 were variable in the PTC, FTC, and nonneoplastic thyroid tissue and were at a lower level of expression of these markers in the overall pattern. ${ }^{46}$ The $\mathrm{CD} 133^{+}$cells were more chemoresistant and radioresistant than $\mathrm{CD} 133^{-}$ATC cells. ${ }^{47}$ The explanation is that CSCs may express a higher level of multidrug resistance adenosine triphosphate-binding cassette pumps, which allow these cells to pump out chemotherapeutic compounds, greatly reducing their effectiveness. ${ }^{48}$

\section{CD44}

CD44 antigen is an $80-250 \mathrm{kDa}$ type I transmembrane glycoprotein that binds hyaluronan and a variety of cell surface ligands such as osteopontin, collagens, and matrix metalloproteinases. In humans, the CD44 antigen is encoded by the CD44 gene located on chromosome $11 \mathrm{p} 13 .{ }^{49}$ The molecule exists in multiple spliced forms and shows enormous variability in glycosylation. CD44 is expressed in a large number of mammalian cell types. It also participates 
in a wide variety of cellular functions including cell-cell interactions, cell adhesion and migration, and tumor metastasis. ${ }^{50}$

It has been noted that the CD44-positive rates are 97\% $(65 / 67)$ in PTC, 56\% (9/16) in follicular adenomas, 50\% $(4 / 8)$ in Hürthle cell neoplasms, $33 \%(5 / 15)$ in medullary thyroid carcinoma, and 38\% (3/8) in FTC by anti-CD44 monoclonal antibody staining. ${ }^{51}$ The study also showed increased expression of CD44 variants compared with normal thyroid tissues in FTC, PTC, and some follicular adenomas. ${ }^{52}$ It is believed that the expression of CD44v3 and CD44v6 variant isoforms might be crucial in the development of nodal metastasis in cases of FTC. ${ }^{53}$ CD44 was detected with an antibody recognizing all forms of CD44, including CD44v3 and CD44v6 variant isoforms, in 213 patients with DTC. PTCs were significantly more often high expressers of CD44s and CD44v6 than FTC $(P<0.001$ for both). Furthermore, it believed that the reduced level of CD44s seems to be an independent prognostic factor for unfavorable disease outcome. ${ }^{54,55}$

\section{Caveolin- I}

Caveolin-1 (CAV-1) is a small protein (21-24 kDa), which is the principal structural component of the cholesterol/ sphingolipid-enriched plasma membrane microdomain caveolae. ${ }^{56}$ The Caveolin family proteins are typically associated with microdomains that are found in the plasma membrane of numerous cells. ${ }^{57}$ The genes of $C A V 1$ and $C A V 2$ are located on chromosome 7 (7q31) and $C A V 3$ on chromosome 3 (3p25). CAV-1 and CAV-2 are most prominently expressed in endothelial, fibrous, and adipose tissues, but the CAV-3 is restricted to striated and smooth muscle. Caveolins' functions include vesicular trafficking, cholesterol homeostasis, cell adhesion, apoptosis, and neurodegenerative disease. CAV-1 could also compartmentalize and concentrate signaling molecules including G-protein subunits and receptor and nonreceptor tyrosine kinases. ${ }^{58}$

CAV-1 has been reportedly overexpressed in cancer cells. ${ }^{59}$ For example, CAV-1 expression was found in malignant thyroid epithelium and more abundantly in tumor stroma but varied in both compartments within and between PTC subtypes. CAV-1 expression in the epithelium was more intense in classical PTC than in the other histological types. On the contrary, stromal CAV-1 expression was stronger in the follicular, solid, and trabecular PTC variants than in classical PTC. ${ }^{60}$ Normal follicular cells did not express CAV-1, but CAV-1 expression in high incidence, and especially in microcancer $(<1.0 \mathrm{~cm}$ in diameter) of papillary carcinoma has been observed. The incidence of CAV-1 expression was significantly reduced in undifferentiated (anaplastic) carcinoma. Therefore, it is assumed that CAV-1 may play an important role mainly in the early phase of papillary carcinoma. ${ }^{61}$ Ito et al reported that CAV-1 was expressed in $96.2 \%$ of the follicular variant of papillary carcinoma and the expression was more frequently expressed in follicular variant of papillary carcinoma than in FTC $(P<0.0001){ }^{62}$

\section{Galectin-3}

The Galectin-3 (LGALS3) is a protein that is encoded by a single gene, $L G A L S 3$, located on chromosome 14, locus $\mathrm{q} 21-\mathrm{q} 22 .^{63}$ The molecular weight of this protein is $\sim 30 \mathrm{kDa}$, and it contains a carbohydrate-recognition-binding domain of $\sim 130$ amino acids that enable the specific binding of $\beta$-galactosides. This protein localizes to the extracellular matrix, the cytoplasm, and the nucleus. It plays a role in numerous cellular functions including cell adhesion, cell activation and chemoattraction, cell growth, differentiation, cell cycle, apoptosis, innate immunity, cell adhesion, and T-cell regulation. ${ }^{63,64}$ It has been known that LGALS3 is distributed widely around the tissues but in a low level.

To date, LGALS3 has been extensively studied as an IHC marker of thyroid malignancy, and a high diagnostic accuracy has been reported even for difficult pathological diagnoses. ${ }^{64}$ Feilchenfeldt et al reported that the mRNA levels of LGALS3 and thyroglobulin in 28 benign and 31 malignant thyroid samples were quantified by real-time PCR. The LGALS3 expression at the mRNA was $60 \%(12 / 20)$ and the protein level was $100 \%(8 / 8)$, respectively. ${ }^{65}$ The positive rate was $84 \%$ (41/49) when combined with the LGALS3 and HBME-1 in PTC specimens. ${ }^{66}$ Two groups of researchers have detected the LGALS3 by IHC in PTC specimens. Saleh et al have shown that the sensitivity and the specificity for LGALS3 were $92.3 \%$ and $77.3 \%$, respectively. ${ }^{67}$ Song et al reported that positive expression of LGALS3 was 97\% (427/441) in PTC group and 51\% (77/151) in the benign thyroid lesions group. ${ }^{68}$ These results may further support the notion that the high level of LGALS3 antigen expression occurs in patients with PTC.

\section{Conclusion and recommendations}

Naturally, the virus could replicate only in the permissive cells. Recent advances in modification of viral surface proteins by genetic manipulation have allowed for altered tropism of the manipulated virus, an approach that has been used successfully. Using what we have discussed on the 
biomarkers to design the TMN oncolytic virus, the outcome of new oncolytic viruses should have a greater potential to achieve the goals of the TMN oncolytic virotherapy.

There are a number of different types of oncolytic viruses that have been altered from natural viruses in the laboratory such as adenovirus, reovirus, measles virus, herpes simplex virus, Newcastle disease virus, and vaccinia virus. ${ }^{69,70}$ An ideal oncolytic virus is one that can specifically target and replicate only in the tumor cells and does not damage normal tissues. Meanwhile, the host immune system will not limit viral replication or clear out from the body before the oncolytic virus destroys the tumor cells. However, when all the tumor cells are eliminated, the oncolytic virus no longer has the ability to replicate in the body. We are consistent with the aforementioned considerations and confident that the infectivity of vesicular stomatitis virus and Newcastle disease virus targeting tumor cells via expanded viral tropism has been modified because the animal viruses could easily avoid human immune-mediated viral clearance. ${ }^{71}$

Over the years, there have been several biological techniques and strategies that have been successfully used in oncolytic virus modifications. ${ }^{72}$ As strategies of producing novel TMN oncolytic therapeutics using the TMN biomarkers, we can summarize as: 1) TSH is a glycoprotein and consists of two subunits: the $\alpha$ subunit and the $\beta$ subunit. The $\alpha$ subunit is responsible for stimulation of adenylate cyclase. The $\beta$ subunit determines its receptor specificity. Expression of
TSH $\beta$ subunit on the selected oncolytic virus for specific binding TSHR is crucial because the binding specificity and affinity is much higher than antibody-antigen binding. ${ }^{71,73}$ 2) Expression of specific antibodies (usually Fab fragments) and specific ligands against TPO, NIS, CD44, CD133, CAV-1, or Galectin-3 could assist the oncolytic virus toward TMN cells. ${ }^{74}$ For example, the TPO protein, 933 amino acid type I dimeric membrane-bound enzyme, is on the surface of thyroid follicular cells ${ }^{75,76}$ that could be targeted by anti-TPO antibodies. ${ }^{76,77} 3$ ) Another approach to design the oncolytic virus is considering the expression of peptide aptamers that can specifically target the TMN biomarkers on the thyroid follicular cells. Theoretically, the peptide aptamers could provide a high affinity-binding surface for a specific target protein. It can be used against any molecular target including small molecules, toxins, peptides, proteins, and even whole cells $^{78}$ (Figure 1).

In spite of the remarkable progress that has been made in the development of oncolytic virotherapy, until now, the work on the seven TMN biomarkers, except for NIS, has not been studied and clinical trials have not been started. Substantial hurdles still remain to enhance onco-specificity, viral antitumor immunity, and administration routes. The lack of understanding of the tight adaptation mechanism of the oncolytic virus to the tumor cell, and in combination with the other therapeutic genes, is still an issue that needs to be addressed. Like any other new treatment procedure, precaution must be taken such as reducing viral toxicity and

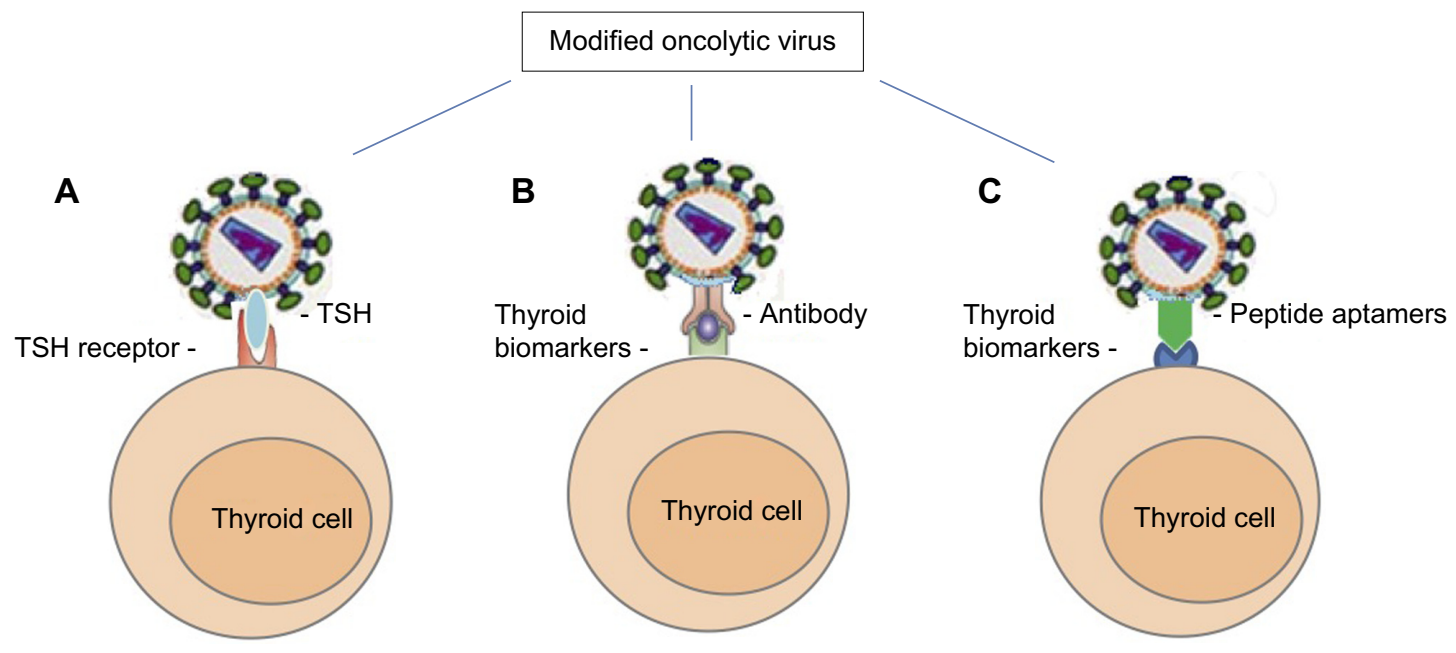

Figure I Oncolytic viral tropism altered by modification of viral surface proteins.

Notes: The modified virus binds with thyroid cell membrane biomarkers including TSHR, TPO, NIS, CD44, CDI33, CAV-I, or Galectin-3. (A) TSH $\beta$ subunit on the selected oncolytic virus for specific binding TSHR on thyroid cells. (B) Expression of specific antibodies against the thyroid membrane-bound biomarkers. (C) Expression of peptide aptamers that specifically target the TMN biomarkers on the thyroid follicular cells.

Abbreviations: CAV-I, Caveolin-I; NIS, sodium/iodide symporter; CD, cluster of differentiation; LGAL3, galectin-3; TMN, thyroid malignant neoplasm; TPO, thyroid peroxidase; TSHR, thyrotropin receptor. 
controlling the spread of virus when considering oncolytic virotherapy for treating thyroid disorders. Researchers should be mindful of these plasma membrane-bound biomarkers and the three strategies discussed earlier in designing TMN oncolytic viruses.

\section{Acknowledgment}

We would like to thank Mr Tsai, KC for English manuscript editing.

\section{Author contributions}

All authors made substantial contributions to conception; took part in revising the article critically for important intellectual content; gave final approval of the version to be published; and agree to be accountable for all aspects of the work.

\section{Disclosure}

The authors report no conflicts of interest in this work.

\section{References}

1. Dean DS, Gharib H. Epidemiology of thyroid nodules. Best Pract Res Clin Endocrinol Metab. 2008;22(6):901-911.

2. Cunningham MP, Duda RB, Recant W, Chmiel JS, Sylvester JA, Fremgen A. Survival discriminants for differentiated thyroid cancer Am J Surg. 1990;160:344-347.

3. Hundahl SA, Fleming ID, Frogmen AM, Menck HR. A National Cancer Data Base report on 53,856 cases of thyroid carcinoma treated in the U.S. 1985-1995. Cancer. 1998;83(12):2638-2648.

4. Saggiorato E, De Pompa R, Volante M, et al. Characterization of thyroid 'follicular neoplasms' in fine-needle aspiration cytological specimens using a panel of immunohistochemical markers: a proposal for clinical application. Endocr Relat Cancer. 2005;12(2):305-317.

5. Persidis A. Cancer multidrug resistance. Nat Biotechnol. 1999;17:94-95.

6. Sethi K, Sarkar S, Das S, Mohanty B, Mandal M. Biomarkers for the diagnosis of thyroid cancer. J Exp Ther Oncol. 2010;8(4):341-352.

7. Glover AR, Lee JC, Sidhu SB. Is there an accurate biomarker test for thyroid cancer recurrence on the horizon? Int J Endo Oncol. 2014;1(1):3-5.

8. Melvin KE, Miller HH, Tashjian AH. Early diagnosis of medullary carcinoma of the thyroid gland by means of calcitonin assay. $N$ Engl $J$ Med. 1971;285:1115-1120.

9. Grogan RH, Mitmaker EJ, Clark OH. Review, the evolution of biomarkers in thyroid cancer-from mass screening to a personalized biosignature. Cancers. 2010;2:885-912.

10. Safran M, Chalifa-Caspi V, Shmueli O, et al. Human gene-centric databases at the Weizmann Institute of Science: GeneCards, UDB, CroW 21 and HORDE. Nucl Aci Res. 2003;31(1):142-146.

11. Binder JX, Pletscher-Frankild S, Tsafou K, et al. Compartments: unification and visualization of protein subcellular, localization evidence. Database (Oxford). 2014;2014:bau012.

12. Loofelt H, Pichon C, Jolivet A, et al. Biochemistry, two-subunit structure of the human thyrotropin receptor. Proc Nail Acad Sci U SA. 1992;89:3765-3769.

13. Davies T, Marians R, Latif R. The TSH receptor reveals itself. Clin Invest. 2002;110:161-164.

14. Barbosa GF, Milas M. Peripheral thyrotropin receptor mRNA as a novel marker for differentiated thyroid cancer diagnosis and surveillance. Expert Rev Anticancer Ther. 2008;8(9):1415-1424.
15. Mizukami Y, Hashimoto T, Nonomura A, et al. Immunohistochemical demonstration of thyrotropin (TSH)-receptor in normal and diseased human thyroid tissues using monoclonal antibody against recombinant human TSH-receptor protein. J Clin Endocrinol Metab. 1994;79(2):616-619.

16. Williams GR. Extra thyroidal expression of TSH receptor. Ann Endocrinol (Paris). 2011;72(2):68-73.

17. Su AI, Wiltshire T, Batalov S, et al. A gene atlas of the mouse and human protein-encoding transcriptomes. Proc Natl Acad Sci U S A. 2004;101(16):6062-6067.

18. Tanaka K, Sonoo H, Yamamoto Y, et al. Changes of expression level of the differentiation markers in papillary thyroid carcinoma under thyrotropin suppression therapy in vivo immunohistochemical detection of thyroglobulin, thyroid peroxidase, and thyrotropin receptor. $J$ Surg Oncol. 2000;75(2):108-116.

19. Chinnappa P, Taguba L, Arciaga R, et al. Detection of thyrotropinreceptor messenger ribonucleic acid (mRNA) and thyroglobulin mRNA transcripts in peripheral blood of patients with thyroid disease: sensitive and specific markers for thyroid cancer. J Clin Endocrinol Metab. 2004;89(8):3705-3709.

20. Wendling P. TSHR mRNA arrives as thyroid cancer marker. Endocrinology. 2010;15:11.

21. Mazzaferri EL. Thyroid carcinoma: papillary and follicular. In: Mazzaferri L, Samaan NA, editors. Endocrine Tumor. Cambridge, MA: Blackwell Scientific Publications; 1993:278-333.

22. Spitzweg C, Morris JC. Review, sodium iodide symporter (NIS) and thyroid. Hormons. 2002;1(1):22-34.

23. Dohan O, De la Vieja A, Paroder V, et al. The sodium/iodide symporter (NIS): characterization, regulation, and medical significance. Endocr Rev. 2003;24:48-77.

24. Dohan O, Carrasco N. Advances in Na+/I- symporter (NIS) research in the thyroid and beyond. Mol Cell Endocrinol. 2003;213(1): $59-70$.

25. Riesco-Eizaguirre G, Santisteban P. A perspective view of sodium iodide symporter research and its clinical implications. Eur J Endocrinol. 2006;155(4):495-512.

26. Tazebay UH, Wapnir IL, Levy O, et al. The mammary gland iodide transporter is expressed during lactation and in breast cancer. Nature Medicine. 2000;6(8):871-878.

27. Biscolla RP, Cerutti JM, Maciel RM. Detection of recurrent thyroid cancer by sensitive nested reverse transcription-polymerase chain reaction of thyroglobulin and sodium/iodide symporter messenger ribonucleic acid transcripts in peripheral blood. J Clin Endocrinol Metab. 2000;85(10):3623-3627.

28. Patel A, Jhiang S, Dogra S, et al. Differentiated thyroid carcinoma that express sodium-iodide symporter have a lower risk of recurrence for children and adolescents. Pediatr Res. 2002;52(5):737-744.

29. Schmutzler C, Winzer R, Meissner-Weigl J, Köhrle J. Retinoic acid increases sodium/iodide symporter mRNA levels in human thyroid cancer cell lines and suppresses expression of functional symporter in nontransformed FRTL-5 rat thyroid cells. Biochem Biophys Res Commun. 1997;240:832-838.

30. Saito T, Endo T, Kawaguchi A, et al. Increased expression of the sodium/iodide symporter in papillary thyroid carcinomas. J Clin Invest. 1998;101(7):1296-1300.

31. Kogai T, Taki K, Brent GA. Enhancement of sodium/iodide symporter expression in thyroid and breast cancer. Endocrinol Relat Cancer. 2006;13(3):797-826.

32. Ruf J, Carayon P. Structural and functional aspects of thyroid peroxidase. Arch Biochem Biophys. 2006;445(2):269-277.

33. Kimura S, Hong YS, Kotani T, Ohtaki S, Kikkawa F. Structure of the human thyroid peroxidase gene: comparison and relationship to the human myeloperoxidase gene. Biochemistry. 1989;28:4481-4489.

34. Gardas A, Lewartowska A, Sutton BJ, Pasieka Z, McGregor AM, Banga JP. Human thyroid peroxidase (TPO) isoforms, TPO-1 and TPO-2: analysis of protein expression in Graves' thyroid tissue. J Clin Endocrinol Metab. 1997;82(11):3752-3757. 
35. Kimura S, Kotani T, McBride OW, et al. Human thyroid peroxidase: complete cDNA and protein sequence, chromosome mapping, and identification of two alternately spliced mRNAs. Proc Natl Acad Sci U S A. 1987;84(16):5555-5559.

36. Weber KB, Shroyer KR, Heinz DE, Nawaz S, Said MS, Haugen BR. The use of a combination of galectin-3 and thyroid peroxidase for the diagnosis and prognosis of thyroid cancer. Am J Clin Pathol. 2004;122(4):524-531.

37. Roddiger SJ, Bojunga J, Klee V, et al. Detection of thyroid peroxidase mRNA in peripheral blood of patients with malignant and benign thyroid diseases. J Mol Endocrinol. 2002;29(3):287-295.

38. Ishikawa T, Miwa M, Uchida K. Quantitation of thyroid peroxidase mRNA in peripheral blood for early detection of thyroid papillary carcinoma. Thyroid. 2006;16(5):435-442.

39. Tanaka T, Umeki K, Yamamoto I, Sugiyama S, Noguchi S, Ohtaki S. Immuno histochemical loss of thyroid peroxidase in papillary thyroid carcinoma: strong suppression of peroxidase gene expression. J Pathol. 1996;179(1):89-94.

40. LazarV, Bidart JM, Caillou B, et al. Expression of the $\mathrm{Na}(+) / \mathrm{I}(-)$ symporter gene in human thyroid tumors: a comparison study with other thyroidspecific genes. J Clin Endocrinol Metab. 1999;84:3228-3234.

41. Yin AH, Miraglia S, Zanjani ED, et al. AC133, is a novel marker for human hematopoietic stem and progenitor cells. Blood. 1997;90(12):5002-5012.

42. Mak AB, Pehar M, Nixon AM, et al. Post translational regulation of CD133 by ATase1/ATase2 -mediated lysine acetylation. $J$ Mol Biol. 2014;426:2175-2182.

43. Chen K, Huang HY, Chen JI. Understanding and targeting cancer stem cells: therapeutic implications and challenges. Acta Pharmacol Sin. 2013;34:732-740

44. Friedman S, Lu M, Schultz A, Thomas D, Lin R-Y. CD133+ anaplastic thyroid cancer cells initiate tumors in immunodeficient mice and are regulated by thyrotropin. PLoS One. 2009;4(4):e5395.

45. Ke CC, Liu RS, Tsai YF, Tseng LM, Lee OK, Lee CH. High pluripotent status and metastatic ability of CD133 positive cells in primary papillary thyroid cancer. J Nucl Med. 2010;51(suppl 2):1128.

46. Liu J, Brown RE. Immunohistochemical detection of epithelialmesenchymal transition associated with stemness phenotype in anaplastic thyroid carcinoma. Int J Clin Exp Pathol. 2010;3(8): 755-762.

47. Ke CC, Liu RS, Yang AH, et al. CD133-expressing thyroid cancer cells are undifferentiated, radioresistant and survive radioiodide therapy. Eur J Nucl Med Mol Imaging. 2013;40(1):61-71.

48. Donnenberg VS, Landreneau RJ, Donnenberg AD. Tumorigenic stem and progenitor cells: implications for the therapeutic index of anti-cancer agents. J Control Release. 2007;122(3):385-391.

49. Spring FA, Dalchau R, Daniels GL, et al. The Ina and Inb blood group antigens are located on a glycoprotein of 80,000 MW (the CDw44 glycoprotein) whose expression is influenced by the In $(\mathrm{Lu})$ gene. Immunology. 1998;64(1):37-43.

50. Aruffo A, Stamenkovic I, Melnick M, Underhill CB, Seed B CD44 is the principal cell surface receptor for hyaluronate. Cell. 1990;61:1303-1313.

51. Figge J, del Rosario AD, Gerasimov G, et al. Preferential expression of the cell adhesion molecule CD44 in papillary thyroid carcinoma. Exp Mol Pathol. 1994;61(3):203-211.

52. Takano T, Sumizaki H, Nakano K, Matsuzuka F, Kuma K, Amino N. Increased expression of CD44 variants in differentiated thyroid cancers. Jpn J Cancer Res. 1996;87(12):1245-1250.

53. Gu J, Daa T, Kashima K, Yokoyama S, Nakayama I, Noguchi S. Expression of splice variants of CD44 in thyroid neoplasms derived from follicular cells. Pathol Int. 1998;48(3):184-190.

54. Böhm JP, Niskanen LK, Pirinen RT, et al. Reduced CD44 standard expression is associated with tumour recurrence and unfavourable outcome in differentiated thyroid carcinoma. J Pathol. 2000;192(3): $321-327$.
55. Samija I, Mateša N, Lukač J, KusićZ. Galectin-3 and CD44v6 as markers for preoperative diagnosis of thyroid cancer by RT-PCR. Diagn Mol Pathol. 2011;20(4):233-241.

56. SmartEJ, GrafGA, McNiven MA, etal. Caveolins, liquid-ordered domains, and signal transduction. Mol Cell Biol. 1999;19(11):7289-7304.

57. Krajewska WM, Masłowska I. Caveolins: structure and function in signal transduction. Cell Mol Biol Lett. 2004;9(2):195-220.

58. Okamoto T, Schlegel A, Scherer PE, Lisanti MP. Caveolins, a family of scaffolding proteins for organizing "preassembled signaling complexes" at the plasma membrane. J Biol Chem. 1998;273(10):5419-5422.

59. Bastiani M, Parton RG. Caveolae at a glance. J Cell Sci. 2010;123: 3831-3836.

60. Paskaš S, Janković J, Marečko I, et al. Caveolin-1 expression in papillary thyroid carcinoma: correlation with clinicopathological parameters and BRAF mutation status. Otolaryngol Head Neck Surg. 2014;150(2):201-209.

61. Ito Y, Yoshida H, Nakano K, et al. Caveolin-1 overexpression is an early event in the progression of papillary carcinoma of the thyroid. $\mathrm{Br} J$ Cancer. 2002;86(6):912-916.

62. Ito $\mathrm{Y}$, Yoshida $\mathrm{H}$, Tomoda $\mathrm{C}$, et al. Caveolin-1 and 14-3-3 sigma expression in follicular variant of thyroid papillary carcinoma. Pathol Res Pract. 2005;201(8-9):545-549.

63. Dumic J, Dabelic S, Flögel M. Galectin-3: an open-ended story. Biochim Biophys Acta. 2006;1760(4):616-635

64. Lerma E. Galectin-1 is overexpressed in myeloid cells and there is a significant different overexpression in cells carrying the BCR-ABL. Chimeric Gene Blood. 2005;106:Abstract4383. [ASH Annual Meeting Abstracts].

65. Feilchenfeldt J, Tötsch M, Sheu SY, et al. Expression of galectin-3 in normal and malignant thyroid tissue by quantitative PCR and immunohistochemistry. Mod Pathol. 2003;16(11):1117-1123.

66. Goli A, Bigotti G, Parente P, Federico F, Castri F, Massi G. Atypical thyroid nodules express both HBME-1 and galectin-3, two phenotypic markers of papillary thyroid carcinoma. J Exp Clin Can Res. 2007;26(2):221-227.

67. Saleh HA, Feng J, Tabassum F, Al-Zohaili O, Husain M, Giorgadze T. Differential expression of galectin-3, CK19, HBME1, and Ret oncoprotein in the diagnosis of thyroid neoplasms by fine needle aspiration biopsy. Cytojournal. 2009;18(6):18.

68. Song Q, Wang D, Lou Y, et al. Diagnostic significance of CK19, TG, Ki67 and galectin-3 expression for papillary thyroid carcinoma in the northeastern region of China. Diagn Pathol. 2011;6:126.

69. Kaufman HL, Kim DW, DeRaffele G, Mitcham J, Coffin RS, Kim-Schulze S. Local and distant immunity induced by intralesional vaccination with an oncolytic herpes virus encoding GMCSF in patients with stage IIIc and IV melanoma. Ann Surg Oncol. 2010;17(3):718-730.

70. Nicklin SA, Baker AH. Tropism-modified adenoviral and adeno-associated viral vectors for gene therapy. Curr Gene Ther. 2002;2(3):273-293.

71. Guan MX, Romano G, Coroniti R, Henderson EE. Review, Progress in oncolytic virotherapy for the treatment of thyroid malignant neoplasm. J Exp Clin Can Res. 2014;33(91):1-11.

72. Coughlan L, Alba R, Parker AL, et al. Tropism-modification strategies for targeted gene delivery using adenoviral vectors. Viruses. 2010;2(10):2290-2355.

73. Wu C, MacLeod I, Su AI. BioGPS and MyGene.info: organizing online, gene-centric information. Nucl Aci Res. 2013;41(Database issue):D561-D565.

74. Nicholson LB, Vlase H, Graves P, et al. Monoclonal antibodies to the human TSH receptor: epitope mapping and binding to the native receptor on the basolateral plasma membrane of thyroid follicular cells. $J \mathrm{Mol}$ Endocrinol. 1996;16(2):159-170.

75. Hobby P, Gardas A, Radomski R, McGregor AM, Banga JP, Sutton BJ. Identification of an immunodominant region recognized by human autoantibodies in a three dimensional model of thyroid peroxidase. Endocrinology. 2000;141:2018-2026. 
76. Bresson D, Rebuffat SA, Péraldi-Roux S. Review, Localization of the immunodominant region on human thyroid peroxidase in autoimmune thyroid diseases: an update. J Autoimmune Dis. 2005;2(2):1-18.

77. Arscott PL, Koenig RJ, Kaplan MM, Glick GD, Baker JR Jr. Unique autoantibody epitopes in an immunodominant region of thyroid peroxidase. J Biol Chem. 1996;271:4966-4973.
78. Huang J, Ru B, Zhu P, et al. Mimo DB 2.0: a mimotope database and beyond. Nucleic Acids Res. 2011;40(1):D271-D277.

\section{Publish your work in this journal}

Oncolytic Virotherapy is an international, peer-reviewed, open access online journal publishing original research, study protocols, reviews, editorials and commentaries on all aspects of oncolytic virology, namely the application of oncolytic viruses for the treatment of cancer. Specific topics in the journal include: Rationale and theoretical aspects of oncolytic virotherapy including in vitro, in vivo and mathematical

Submit your manuscript here: http://www.dovepress.com/oncolytic-virotherapy-journal

\section{Dovepress}

modeling; and practical application and problem solving in the clinic including identification of potential responders through biomarkers and genetic profiling. The manuscript management system is completely online and includes a very quick and fair peer-review system, which is all easy to use. Visit http://www.dovepress.com/ testimonials.php to read real quotes from published authors. 